Dylewski Michal, Dylewska Monika, Kasprzak Alicja, Bednorz Roman, Maliszewski Jakub, Cygoń Krzysztof, Boczula Joanna. Proposition of patient stratification and parameter setting for mechanical traction in patients with LBP. Journal of Education, Health and Sport. 2020;10(2):85-96. eISSN 2391-8306. DOI http://dx.doi.org/10.12775/JEHS.2020.10.02.012

https://apcz.umk.pl/czasopisma/index.php/JEHS/article/view/JEHS.2020.10.02.012

https://zenodo.org/record/3668802

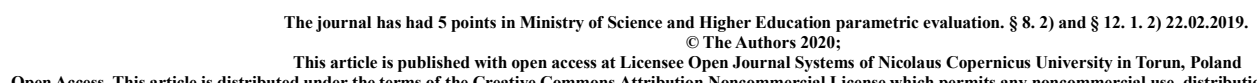

This article is published with open access at Licensee Open Journal Systems of Nicolaus Copernicus University in Torun, Poland
Open Access. This article is distributed under the terms of the Creative Commons Attribution Noncommercial License which permits any noncommercial use, distribution, and reproduction in any medium, provided the original author (s) and source are credited. This is an open access article licensed under the terms of the Creative Commons Attribution Non commercial license Share alike.
(http://creativecommons.org/licenses/by-nc-sa/4.0/) which permits unrestricted, noe The authors declare that there is no conflict of interests regarding the publication of this paper-
Thentistion and

Received: 15.01.2020. Revised: 25.01.2020. Accepted: 16.02.2020

\title{
Proposition of patient stratification and parameter setting for mechanical traction in patients with LBP
}

\section{Propozycje sposobu doboru pacjentów i parametrów trakcji mechanicznej kręgosłupa lędźwiowego}

\section{Michał Dylewski ${ }^{1,2}$, Monika Dylewska ${ }^{3}$, Alicja Kasprzak ${ }^{4}$, Roman Bednorz ${ }^{4}$, Jakub Maliszewski ${ }^{4}$, Krzysztof Cygoń ${ }^{4}$, Joanna Boczula ${ }^{4}$}

1 Klinika Uzdrowiskowa „Pod Tężniami” im. Jana Pawła II w Ciechocinku

2 Leśny Dom Seniora w Piastowie

3 Sanatorium Uzdrowiskowe „Promień” w Ciechocinku

4 P.H.U. Technomex Sp. z o.o.

Work prepared as part of the project:

„Kompleksowa diagnostyka i rehabilitacja pacjentów z zespołami bólowymi kręgosłupa oraz zagrożonych upadkiem z wykorzystaniem innowacyjnej terapii”

współfinansowanego z Europejskiego Funduszu Rozwoju Regionalnego w ramach projektu pn. „Fundusz Badań i Wdrożeń” realizowanego w ramach Osi Priorytetowej 1. Wzmocnienie innowacyjności i konkurencyjności gospodarki regionu, Działania 1.2 Promowanie inwestycji przedsiębiorstw w badania i innowacje, Poddziałania 1.2.1 Wsparcie procesów badawczo-rozwojowych Regionalnego Programu Operacyjnego Województwa Kujawsko-Pomorskiego na lata 2014-2020. 


\section{Sumary:}

Mechanical traction of the lumbar spine remains a procedure very willingly used by therapists in many countries of the world, despite at least equivocal scientific evidence. One of the problems reducing its effectiveness is the problem with the selection of patients for therapy as well as selecting the therapeutic goals and treatment parameters for the patient in an individualized and, at the same time, repeatable manner. In this work, the authors presented such a model developed as part of Research and Development works carried out at the Leśny Dom Seniora in Piastów.

\section{Streszczenie:}

Trakcja mechaniczna kręgosłupa lędźwiowego pozostaje zabiegiem bardzo chętnie stosowanym przez terapeutów $\mathrm{w}$ wielu krajach świata, pomimo co najmniej niejednoznacznych dowodów naukowych. Jednym z problemów zmniejszających jej skuteczność jest problem zarówno z doborem pacjentów do terapii, jak i celu terapeutycznego i parametrów zabiegowych do pacjenta w sposób zindywidualizowany, a jednocześnie powtarzalny. W niniejszej pracy autorzy przedstawili taki model wypracowany w ramach prac Badawczo-Rozwojowych prowadzonych w Leśnym Domu Seniora w Piastowie.

Key Words: Low Back Pain, Mechanical traction, Lumbar Spine

\section{INTRODUCTION}

One of the most common health problems are undoubtedly pain syndromes of the lumbar spine, touching at least once in a lifetime up to $80 \%$ of general population $[1,2,3,4]$, significantly affecting patient's quality of life [3,4]. While most of these episodes is spontaneously improved in less than four weeks, as many as 60 to 80 percent of them reoccurs within a year after the first symptoms [5]. What is even worse, in 10 to 30 percent of patients with lumbar pain syndrome these symptoms will go into a chronic condition $[3,4]$. The high percentage of people suffering from this ailment, frequent relapses, and especially relatively easy transition into a chronic state cause lumbar back pain generating very large costs. This costs may be economic, related to treatment cost and work absence, as well as social, associated with the reduction of activity and impact on daily activities of patients $[1,3,4,6,7,8]$. The complexity of this area, great number of possible dysfunction, causes and sources of pain makes Low Back Pain still a huge problem for both diagnostic and therapy $[8,9,10]$. Up to 90 percent of pain syndromes in this area is described as non-specific, ie not associated with a diagnosed pathology, in which it is difficult to clearly determine the cause and mechanism of ailments, and often even the source of pain $[8,11]$. No wonder that there is no general consensus on how to treat back pain - sometimes even the existence of a single universal approach is doubtful. Thus different, often divergent assessment of use of the available therapeutic agents are nothing surprising $[7,9,12,13,14,15,16]$.

One of such method with a very long history of use in the treatment of pain syndromes of the spine is a mechanical traction [18]. Although in recent years the scientific evidence presented in the literature are discrepant, presenting arguments both for and against its effectiveness $[19,20,21,22,23]$, in many countries of the world it is still used and evaluated by therapists as very effective [24,25,26,27,28,29,30,31]. 
One of the fundamental problems associated with the use of mechanical traction of the lumbar spine, similar as in other forms of therapy, is appropriate qualification of patients for treatment, the selection of therapeutic targets and therapy parameters [7,12,32,33,34,35].

In this paper authors present a proposal relating to the above problems, established as an effect of project "„Kompleksowa diagnostyka i rehabilitacja pacjentów z zespołami bólowymi kręgosłupa oraz zagrożonych upadkiem z wykorzystaniem innowacyjnej terapii”

co-financed by the European Regional Development Fund within the framework of the project entitled,,Fundusz Badań i Wdrożeń" " implemented under Priority Axis 1. "Wzmocnienie innowacyjności i konkurencyjności gospodarki regionu, Operation 1.2 "Promowanie inwestycji przedsiębiorstw w badania i innowacje", Suboperation 1.2.1 "Wsparcie procesów badawczo-rozwojowych Regionalnego Programu Operacyjnego Województwa Kujawsko-Pomorskiego na lata 2014-2020".

\section{INDICATIONS AND CONTRAINDICATIONS}

Just like any therapeutic procedure, the mechanical traction of the lumbar spine has specific indications and contraindications for its implementation. The most frequently mentioned in the literature contraindications are [20,36,37,38]:

- Osteoporosis

- Direct compression of the spinal cord, myelopathy

- tumors of the spine

- Implants in the lumbag spine

- $\quad$ Neurological symptoms of segment S4

- Cauda equina syndrome

- $\quad$ Spondylolisthesis

- Hypermobility or spinal instability

It is worth to mention, that a necessary element for the implementation of the mechanical traction of the spine (as well as any other treatment) is patient consent on suggested form of therapy. In the case of children, consent must be given by their parents or legal attendant of the patient.

In addition to contraindications related to the spine, there are contraindications related to the general state of health, which will prevent the treatment or increase the risk associated with it. In the project the following factors has been taken into account.

- Unstable clinical condition of cardio-respiratory system

- Features of cardiopulmonary failure - class III or IV according to NYHA

- Inability to walk unaided

- States after fractures or spinal surgery

- Situations in which it is contraindicated to increase the pressure in the abdomen and / or chest

- Failure to cooperate with therapist (understanding and command execution), mental disorders

- Existing urgent indications for surgery 
- Possible indication for urgent surgery until their exclusion

It is worth mentioning that age in itself (old or senile) was not made a contraindication to spinal mechanical traction. It requires only accurate exclusion of diseases which occurence in older age is more frequent.

As indications for mechanical traction of lumbar spine were recognized:

- $\quad$ The presence of lumbar pain or pain radiating peripheral from the spine

- $\quad$ The occurrence of pain, lumbar pain or radiating / reffered peripheral from the spine in patient history with occurring currently dysfunction or mechanical impairment

- $\quad$ Positive neurodynamic tests indicating irritation / nerve root sliding disorder

- Limitation of motion of the lumbar spine

- $\quad$ Positive results in Backache Index test

For the assessment of indications we also used elements from the patient history, clinical tests (Valsalva test, three-phase extension test, Goldwaithtest).

The evaluation study also excluded in functional examination hips disorders (mobility assessment, Anvil test) and sacroiliac joints (provocation tests, Pidelou test, Derbololowski test).

In the case of undesired reactions or when the therapy is ineffective up to 5treatments according to the accepted treatment methodology - the mechanical traction were terminated, implementing the execution of other therapeutic agents, and if necessary extending diagnostics.

\section{POSTULATED EFFECTS OF MECHANICAL TRACTION}

The primary effect of mechanical traction is separation of vertebral bodies from each other. In the lumbar spine observed in studies conducted in the eighties of the twentieth century, such separation ranged from 1 to $3 \mathrm{~mm}$, which is increasing the distance between the vertebral bodies by about 8-25 percent. Thanks to that separation may occur other mechanisms which may be directly connected with therapeutic effects $[39,40,41,42,43]$.

The negative intradiscal pressure (Suction phenomenon) is associated with an increase in the space between the vertebral bodies so that the mass of the disc, in particular a nucleus pulposus must be spread over a larger volume. This results in a situation in which inside the annulus fibrosus for some time the pressure is lower than that outside the ring. The pressure difference reach up to $100 \mathrm{mmHg}$ at a maximum traction force (about $50 \mathrm{Kg}$ ) [44,45,46]. In principle, this should result in the force which causes movement of the material ofnucleus pulposus hernia towards the center, reducing its volume[42]. These effects, however, has its limitations connected with the state of degeneration of the intervertebral disc, both the nucleus pulposus and the annulus fibrosus [43]. An additional element that may reduce and change of the shape of the hernia of the nucleus pulposus is the increased tension of soft tissue between the vertebrae. This applies mainly to the fibers of the annulus fibrosus as well as the interbody ligaments - specially the posterior longitudinal ligament. Its tension, in particular for subligamental hernia, may trigger a force acting inwards, which may reduce - and certainly 
flatten protuberance $[42,47,48,49]$. One have to remember that he change the shape or size of protrusion may improve the clinical condition of the patient and reduce the pressure on the innervated tissues. Complete removal of hernia through conservative treatments may not be needed for that - and in the opinion of the authors is not possible in a non-operational treatment.

Increasing volume of intervertebral foramen. This is another effect of mechanical traction of the spine that can have a direct impact on the therapeutic effect $[36,37,40,41,43$. This increases the amount of space in which there are, among others, nervous tissue, and consequently may reduce or eliminate the irritation of the nerve roots. This effect may be independent of the cause of irritation (edema associated with inflammation, protuberance, or other structure). A decrease in mechanical compression on the nerve roots improves blood circulation, accelerates ceasing infection or improve nerve conduction and nerve sliding $[43,48,49,50]$.

For lumbar spine, increase of volume of intervertebral foramens is considered to be dependent on the traction force in the range of about 10 to $50 \mathrm{Kg}[43,50]$.

Mechanical traction of the lumbar spine, in particular manufactured from a force changing during treatment, may also cause the relief of facet joints, as well as improving nutrition of intervertebral joints and soft tissue in this area. The alternating forces of compression and decompression of the articular surfaces, variable forces on the soft tissue may cause, in addition to improved nutrition and blood supply, a reflex relaxation of the soft tissue. This also applies to relaxation of tight paraspinal muscles, which, at the beginning of mechanical traction may increase its tension, but then very quickly become loosened. According to the available papers 4 to 7 minutes (depending on the type of muscle and the force of traction) is usually sufficient to reduce muscle tension to resting values. [51,52].

Separation vertebral bodies from each other, as well as the articular surfaces, causes the dismissal of the attachments of ligaments and joint capsules, stretching them. Therefore, effect of mechanical traction is also increased range of motion of the spine associated with the increased elasticity of contracted soft tissues - especially these inserted to adjacent vertebrae.

With such diverse actions traction can be used to create so-called suction phenomena using a submaximal static force, but also to increase the range of motion of the spine, nerve root decompression in case of its conflict, as well as improving the nutrition of the joints, antiinflammatory and reflex relaxation of paraspinal muscles. Both in the research project and after its completion, the mechanical spinal traction were conducted using three-dimensional mechanical spinal traction table - Platinum produced by Technomex from Poland.

The possibility of a three-dimensional settings of the distal part of the table while maintaining the performance of traction is very important when performing this procedure. This is because the optimal selection of patients for therapy. Optimum mechanical traction axis (not stretching the soft tissue on one side) takes place in a situation where the patient's spine in the treatment area is in neutral position - dyslordosis, without rotation or the side flexion [43]. However, in the case of asymmetric setting of the spine in patients may be necessary correction of the table to achieve the desired position of the patient's spine.

The second, though from authors point of view primary principle of performing this treatment is the need for positioning the patient in painless position, or with minimal pain in acute 
phase. that will not increase during treatment. Thus sometimes to obtain desired position 3dimensional setting of device is necessary to adapt position to momentary condition and ability of patient.

\section{SELECTION OF THERAPEUTIC GOALS AND TREATMENT PARAMETERS}

One of the basic conditions for each treatment efficacy is an individual matching for the current needs and condition of the patient. This concerns not only the selection of treatment parameters, but perhaps above all, the selection of the type and form of treatment. In research funded by the project work, the qualification was carried out in three steps.

The first stage is the classification of a patient for mechanical traction of the lumbar spine. The condition for application of this form of therapy was the presence indications, lack of contraindications, and, of course, the patient's consent agreement for the execution of the proposed therapy. Indications and contraindications are described earlier in this text. It is worth noting that the pain in the lumbar area was not in itself sufficient indication for traction. Using the clinical tests and functional examination to confirm both the origin of pain from specific tissues of the spine and / or peri-spinal, and exclusion symptoms origin of other structures, in particular hip joints (mobility assessment, Anvil Test) and the sacroiliac joints (Derbolowski test, Pidelou test, provocation tests according to M. Laslett). This is especially important in this area, because localization of pain or even Radiological examination seems not to be sufficient to set correct diagnosis about source of patient complains.

The second stage of the proposed algorithm was to determine the primary goal of the therapy with the use of mechanical traction. These objectives were linked to a large extent with the effects of traction on the patient, as described above. On the other hand, in the projest we set the framework of the specific elements in interview (symptoms and their variability over time) and tests for determining the selection of the basic therapeutic goals for the patient.

Based on the objectives listed below, biomechanical studies available in the literature and clinical experience we have determined the parameters of mechanical traction of the lumbar spine attempting to serve best to achieve the desired therapeutic effect.

Below are the different therapeutic targets, along with typical symptoms and tests, as well as the parameters used in the project and after its completion to achieve them.

\section{Objective: The decreasing of nucleus pulposus protrusion (suction phenomenon).}

a. Patient characteristics: age less than 65 years, the symptoms of nerve root irritation very likely, sudden onset / worsening of symptoms at the beginning of the central, within a few / several hours spreading in the distal direction.

b. Symptoms and Tests: Valsalva test is often positive, pronounced variability of symptoms in time, possible forced position of the spine, most likely positive neurodynamic tests.

c. The treatment parameters: the maximum force target (the smaller of $-50 \mathrm{Kg}$, or $60 \%$ of body weight), the static traction, time 12 to 15 minutes. First treatment can be performed with a smaller force increasing progressively to reach desired value within 3 - 4 treatment.

\section{Objective: The effect of increasing the intervertebral foramens, nerve root decompression}


a. Patient characteristics: age over 40 years, the sudden onset of pain right away to the leg or only locally in the lumbar region, less often in the buttock. Possible slow start - no apparent reason. Symptoms of sciatica pain / femur may be present, but especially in chronic conditions can be reduced. Present positive neurodynamic tests, often paresthesia, symptoms of muscle weakness can also be present in neurological examination. Symptoms of nerve irritation in the chronic states can dominate the symptoms of pain, especially locally, in the lumbosacral area.

b. Symptoms and Tests: Valsalva test often negative, positive neurodynamic tests, oftenpositive tests for compression of nerve roots in the intervertebral foramens. In the BAI test mostly pain during the side bending and rotation towards the pain.

c. The treatment parameters: Force gradually increased from about $25 \%$ of the body weight every $4 \mathrm{~kg}$ per treatment, to obtain satisfactory results (the elimination of symptoms and improvement in the neurodynamic tests). Type of traction changeable (intermittent) maximal force holding time of about 120 seconds and then 30 seconds power reduced by $30 \%$. Time 12 to 15 minutes.

\section{Objective: decompression and nutrition of the articular surfaces, increasing the flexibility of soft tissues}

a. Patient characteristics: No neurological symptoms, including negative neurodynamic tests. Local pain, sometimes radiating to the sacral / buttock. The pain can be exacerbated by the prolonged standing, walking - activities that increase compression joints. Limited range of motion, pain or end of the motion or no apparent pain. Pain persists or decreases after a rest, increases after exercise.

b. Symptoms and Tests. Neurodynamic tests negative, negative symptom of Valsalva, limited range of motion. The BAI test often positive, but without the sharp, radiating pain to the extremities.

c. Treatment parameters: Force $25-35 \%$ of body weight, traction force variable course: intermittent. Maintaining maximum strength $90-120$ seconds, a reduction of $15 \%$ for 30 seconds. Duration 15 minutes.

d. Notes: If a patient has symptoms associated with irritation of the nerve roots, perform first operations associated with increasing volume of intervertebral foramen and decompression of the nerve root.

\section{Objective: a nutritional, analgesic - refectory reduction of acute pain.}

a. Patient characteristics: acute pain, radiating or just around Lumbar area. Valsalva test is usually positive. Movement in every or nearly every direction causes or intensifies the pain. Often forced position (according to pain) of the patient or restriction of movement. Increased automatically (defensive) paraspinal muscle tension.

b. Symptoms and Tests: No evaluation of mobility / stability of the spine possible, no or very limited functional assessment.

c. Treatment parameters: Force variable in time, the maximum value in higher phase to approx. $16 \mathrm{~kg}$, the maximum value in the phase of reducing below $10 \mathrm{Kg}$. Running traction with variable strength, type of Intermittent (rectangular) or Harmonic (sinusoid). The duration of the maximum strength of 20 seconds, minimum force 20 seconds, a rise time and fall time 
forces a slow - after 20 seconds. Duration 10 to 12 minutes. In this case, the position during surgery, above all Painless, using the possibility of setting the distal part of the table spatial depending on the forced position of the patient. Traction can be performed in prone or supine position.

d. If the relief of symptoms carry out, an evaluation of the patient as soon as possible is recommended and qualifies for the appropriate form of therapy. When the symptoms do not decrease after 2-4 treatments, changing the way of treatment. In the event of a deterioration in the treatment of ailments abort traction immediately.

In any case, the emergence or worsening of symptoms during the treatment of mechanical traction of the lumbar spine should be a reason for immediate discontinuation of the treatment. The decision on the possible continuation of traction should be taken only after explaining the causes of ailments.

\section{CONNECTING WITH OTHER FORMS OF THERAPY}

Mechanical traction in the authors' opinion should not be the only therapeutic procedure for the treatment of pain syndromes of the lumbar spine. The complexity of the problem, many coexisting illnesses, dysfunction and changes in the structure of tissues causes that to achieve optimal therapy results therapy itself should also be complex. During mentioned above project, a model were created to combine a specific oriented mechanical traction with other forms of therapy - mostly exercises for different purposes and form. Their selection was based on the functional and biomechanical examination, the results of which were a direct indication to physiotherapy choice. Exercise and a limited amount of manual techniques aimed at reduction or elimination of dysfunction, and where it was impossible to control their compensation.

The main, except traction, therapeutic module were exercises increasing the range of motion of the spine (globally), and above all the strength and coordination of trunk muscle. They were performed with the use of the phenomenon of biofeedback, using TERGUMED devices. This kind of exercises were used both as addiction to traction, or without it if traction were not indicated. The most important, however, in the opinion of the authors is the inclusion to the treatment plan goals based on functional and biomechanical assessment and individualized selection of parameters, and the type of device or form of training is a secondary thing.

Another frequently used element of the training exercise was local (or core) stabilization. The stability of the local movement patterns and lumbar pelvic complex in the majority of patients showed significant deficiencies in this regard. Our choice was based on the principles of sensorimotor training according to Janda, however, one could apply here other methods of pursuing similar goals.

When neurodynamic tests proved positive, therapy included appropriate exercise neuromobilizations. They were performed with a therapist or as a form of self-therapy for the patient after having carried out instruction by a physiotherapist.

Wherever possible, the time (unit exercises are scheduled for about 90 minutes) and the ability of the patient was also fed other forms of therapy, depending on the detected dysfunctions that can affect even indirectly to the formation of pain syndromes. Exercises increasing the range of motion of peripheral joints (eg. extension of the hip joints) muscle 
relaxation or stretching (often illiopsoas muscles, the erector spinae, hamstrings, piriformis muscle or calf muscles). In the case of peripheral muscle weakness resistance exercises were performed to increase it. As a separate therapeutic target qualified exercise to improve coordination - corrective movement patterns during normal operation. For this purpose, we used ACX devices which supprts training with biofeedback phenomenon.

\section{SUMMARY}

Mechanical traction of the lumbar spine, despite the ambiguous results of studies $[19,20,21,22,23]$, remains in many countries treatment often used in the treatment of Low Back pain [24,25,26,27,28,29,30 31]. One of the reasons for the lack of evidence supporting its effectiveness in the work of inspection in recent years is the poor quality of research, postulated by the authors of these works [19,20,22,23]. One problem is the lack of reproducible method for differentiating patients with back pain for more specific sub-group in the context of a mechanical traction [7,13,22,23]. Only such subgroups may have to be eligible for the treatment, and further differentiation to help patients choose the optimal treatment in those who qualify for it. Another problem is the treatment of the traction (like many others) as a form of monotherapy. With such a complex, multi-faceted problem of such an approach - looking for some form of therapy to be able to have a positive effect on all patients seems to be doomed to failure. [12] Hence the text presented a way to therapeutic, complex algorithm for selecting patients for treatment of traction and its connection with other forms of therapy dependent directly from the functional and biomechanical evaluation can be a good solution. At the same time the authors are aware of the difficulties of research, because presented method of selection of goals and therapies depending on the functional status makes very difficult or even impossible creation of both homogeneous research group or repeatable therapy in different patient.

\section{BIBLIOGRAPHY}

1. Andersson GB "Epidemiological features of chronic low-back pain" Lancet 1999; 354(9178): 581-5

2. Biering-Sorensen $\mathrm{F}$ “A prospective study of low back pain in a general population: I. Occurrence, recurrence, and etiology" Scand J Rehabil Med 1983; 15(2): 71-79

3. Dagenais S, Caro J, Haldeman S "A systematic review of low back pain cost of illness studies in the United States and internationally" Spine J 2008; 8(1): 8-20

4. Katz JN "Lumbar disc disorders and low-back pain: socioeconomic factors and consequences" J Bone Joint Surg Am 2006; 88(Suppl 2): 21-4

5. Hides JA, Richardson CA, Jull GA "Multifidus muscle recovery is not automatic after resolution of acute, first episodes low back pain" Spine 1996; 21:2763-9

6. Kiwerski J. „Rehabilitacja Medyczna” Wyd. Lekarskie PZWL, W-wa 2007

7. Kamper SJ et al.. „Treatment-based subgroups of low back pain: A guide to appraisal of research studies and a summary of current evidence" Best Practice \& Research Clinical Rheumatology 2010; 24: 181-191

8. Savingy $\mathrm{P}$ et al. "Low back pain: early management of persistent non-specific low back pain. Full guideline" London: National Collaborating Centre for Primary Care and Royal 
College of General Practitioners http://www.nice.org.uk/nicemedia/pdf/CG88fullguideline.pdf; May 2009

9. Koes BW, van Tulder MW, Ostelo R, Burton AK, Waddell G "Clinical guidelines for the management of low back pain in primary care. An international comparison" Spine 2001; 26: 2504-2514

10. Adams M "Biomechanika bólu kręgosłupa” DB Publishing, Warszawa 2006. Wyd 2

11. Chou R, Qaseem A, Snow V, et al. "Diagnosis and Treatment of Low Back Pain: a joint clinical practice guideline from the american college of physicians and the American Pain Society" Ann Intern Med 2007; 147(7): 478-91

12. Delitto A "Research in low back pain: time to stop seeking the elusive <magic bullet>" Phys Ther 2005; 85(3): 202-4.

13. Fritz JM, Cleland JA, Childs JD "Subgrouping patient with low back pain: evolution of a classification approach to physical therapy" J Orthop Sports Phys Ther 2007; 37: 290-302)

14. Kent P, Keating J "Do Primary-Care Clinicians Think That Nonspecific Low Back Pain Is One Condition?” Spine 2004; 29(9): 1022-31

15. Kent $\mathrm{P}$, Keating JL "Classification in nonspecific low back pain: what methods do primary care clinicians currently use? [Research Support, Non-U.S. Gov't]" Spine 2005; 15;30(12):1433-40.

16. van Tulder MW et al. "European guidelines for the management of acute nonspecific low back pain in primary care" 2004 European Commission, Research Directorate General. COST B13 Working group [http://www.backpaineurope.org]

17. Waddell G, McIntosh A, Hutchinson A, Feder G, Lewis M "Low back pain evidence review" Royal College of General Practitioners 1999, London

18. Marketos SG, Skiadas P. „Hippocrates. The father of spine surgery” Spine 1999; 24: 1381-7.

19. Harte AA, Baxter GD, Gracey JH "The efficacy of traction for back pain: a systematic review of randomized controlled trials" Arch Phys Med Rehabil 2003; 84(10): 1542-53

20. Krause M, Refshauge KM, Dessen M, Boland R "Lumbar spine traction: evaluation of effects and recommended application for treatment" Man Ther 2000; 5: 72-81.

21. van Tulder MW, Koes B, Malmivaara A "Outcome of non-invasive treatment modalities on back pain: an evidence-based review" Eur Spine J 2006b; 15(Suppl.): S64-81.

22. Clarke JA et al. "Traction for low-back pain with or without sciatica" Cochrane Database Syst Rev 2007 ;2: CD003010

23. Gay RE,. Brault JS, "Evidence-informed management of chronic low back pain with traction therapy" The Spine Journal 2008; 8: 234-242

24. Harte AA, Gracey JH and Baxter GD "Current Use of Lumbar Traction in the Management of Low Back Pain: Results of a Survey of Physiotherapists in the United Kingdom” Arch Phys Med Rehabil 2005; 86: 1164-1169

25. Li LC, Bombardier C "Physical therapy management of low back pain: an exploratory survey of therapist approaches" Phys Ther 2001; 81(4): 1018-28

26. Poitras S, Blais R, Swaine B et al. „Management of Work-Related Low Back Pain: A Population-based Survey of Physical Therapists” Phys Ther 2005; 85:1168-81 
27. Webster BS, Courtney TK, Huang YH et al. "Survey of Acute Low Back Pain Management by Specialty Group and Practice Experience” J Occup Environ Med 2006; 48: 723-32

28. Foster NE, Thompson KA, Baxter GD, Allen JM. Management of non-specific low back pain by physiotherapists in Britain and Ireland. Spine 1999;24:1332-42

29. Gracey JH, McDonough SM, Baxter GD. Physiotherapy management of low back pain: a survey of current practice in Northern Ireland. Spine 2002;27:406-11

30. Van der Heijdan GJ, Beurskens AJ, Dirk MJ, Bouter LM, Lindeman E. Efficacy of lumbar traction: a randomised clinical trial. Physiotherapy 1995;81:29-35

31. Jette AM, Delitto A. Physical therapy treatment choices for musculoskeletal impairments. Phys Ther 1997;77:145-54

32. Fritz JM et al "Is There a Subgroup of Patients with Low Back Pain Likely to Benefit from Mechanical Traction? Results of a Randomized Clinical Trial and Subgrouping Analysis" Spine 2007; 32(26): E793-E800

33. Raney $\mathrm{N}$ et al. "Development of a clinical prediction rule to identify patients with neck pain likely to benefit from cervical traction and exercise" Eur Spine J 2009; 18: 382-391

34. Congcong Cai, Yong Hao Pua, Kian Chong Lim “A clinical prediction rule for classifying patients with low back pain who demonstrate short-term improvement with mechanical lumbar traction" Eur Spine J 2009; 18: 554-561

35. Fritz J M, Thackeray A, Childs J D, Brennan G P "Randomized clinical trial of the effectiveness of mechanical traction for sub-groups of patients with low back pain: study methods and rationale" BMC Musculoskeletal Disorders 2010, 11:81

36. Saunders DH "Lumbar Traction" The Journal of orthopedic and sport physical therapy 1979; pp $36-42$

37. Saunders DH "The Controversy over Traction for Neck and Low Back Pain" Physiotherapy; 1998, vol 84, no 6: 285-289

38. Saunders HD, Ryan RS "Evaluation, Treatment and Prevention of Musculoskeletal Disorders, Volume 1: The Spine" The Saunders Group, Chaska, MN 2004. 4th Edition

39. Kane MD, Karl RD, Swain JH "Effects of Gravity-Facilitated Traction on Intervertebral Dimensions of the Lumbar Spine" JOSPT 1985, Vol. 6, No. 5

40. Onel D, Tuzlaci M, Sari H, et al. "Computed Tomographic Investigation of the Effect of Traction on Lumbar Disc Herniations" Spine 1989;14: 82-90

41. Sari H, Akarirmak U, Karacan I et al „Computed tomographic evaluation of lumbar spinal structures during traction” Physiother Theory Pract 2005; 21: 3-11.

42. Mathews JA "Dynamic discography: A study of lumbar traction" Ann Phys Med 1968; IV: 275-279

43. Gay RE et al.. "Stress in lumbar intervertebral discs during distraction: a cadaveric study" Spine J 2008; 8: 982-90

44. Ferrara L, Triano JJ, Sohn MJ et al. "A biomechanical assessment of disc pressures in the lumbosacral spine in response to external unloading forces" Spine J 2005; 5: 548-53.

45. Ramos G, Martin W "Effects of vertebral axial decompression on intradiscal pressure" $\mathrm{J}$ Neurosurg 1994; 81: 350-3.

46. Ranu HS "Measurement of pressures in the nucleus and within the annulus of the human spinal disc: due to extreme loading" Proc Inst Mech Eng H 1990; 204: 141-6. 
47. Gupta RC, Ramarao SV "Epidurography in the Reduction of Lumbar Disc Prolapse by Traction. Archives of Physical Medicine and Rehabilitation 1978; 59: 322-327

48. Ozturk B et al "Effect of continuous lumbar traction on the size of herniated disc material in lumbar disc herniation" Rheumatol Int 2006; 26: 622-626

49. Saal JA, Saal JS "Nonoperative Treatment of Herniated Lumbar Intervertebral disc with Radiculopathy. An Outcome Study" Spine 1989; 14(4): 431-437

50. Meszaros T, et al. "Effect of 10\%, 30\% and 60\% Body Weight on the Straight Leg Raise Test of Symptomatic Patients with Low Back Pain" J Orthop Sports Phys Ther 2000; 30(10): 595-601

51. Cholewicki J et al. "Trunk muscle response to various protocols of lumbar traction" Manual Therapy 2009; 14: 562-566

52. Letchuman R, Deusinger RH "Comparison of sacrospinalis myoelectric activity and pain levels in patients undergoing static and intermittent lumbar traction" Spine 1993; 18(10): $1361-5$

Michał Dylewski

Osoba do kontaktu

micdyl@,02.pl

Koordynator d.s. Rozwoju Rehabilitacji w Klinice uzdrowiskowej "Pod Tężniami" w Ciechocinku Wykładowca w Bydgoskiej Szkole Wyższej w Bydgoszczy

Wieloletni członek Komitetu naukowego corocznej międzynarodowej konferencji "Życie bez Bólu" Autor/ współautor ponad 60 publikacji naukowych

Doktorant Wydziału Rehabilitacji Akademii Wychowania Fizycznego w Krakowie

Monika Dylewska

Monikadylewska562@gmail.com

Alicja Kasprzak

Kasprzak@technomex.pl

Roman Bednorz

Bednorz@technomex.pl

Jakub Maliszewski

jmaliszewski@technomex.pl

Krzysztof Cygoń

kcygon@technomex.pl

Joanna Boczula

jboczula@technomex.pl 